ら徐放錠としての一応の特性は表れていると思わ れる.

また 0 から $24 \mathrm{hr}$ までの AUC を比較してみる と Tab. 3 に見られるように, 従来の $100 \mathrm{mg}$ カプ セル 1 日 3 回投与と $150 \mathrm{mg}$ 錠 2 回投与の值が $25.9(\mu \mathrm{g} \cdot \mathrm{hr} / \mathrm{ml})$ と $26.8(\mu \mathrm{g} \cdot \mathrm{hr} / \mathrm{ml})$ でほぼ同 様な値を示している，従って $100 \mathrm{mg}$ カプセル剤 が disopyramide, $150 \mathrm{mg}$ 徐放錠は塩基がついた disopyramide phosphate と両者は若干異なって はいるが，生体内に入った場合は活性部分が同じ であるため，1 日総投与量が同じ場合には 1 日当 たりほぼ同等の薬物量が体内に存在することにな る. $200 \mathrm{mg}$ 錠 2 回投与はやや低めの值 29.2 $\mu \mathrm{g} \cdot \mathrm{hr} / \mathrm{ml}$ を示してるが, AUC と投与量の関係 を示した Fig. 4 を参考にすると, 投与量の増加 に比較し AUC の伸びはあまり顕著でなかった. その原因は不明である。

次に半減期からカプセルおよび各徐放錠を比較 すると, 通常のカプセル剂の $8.5 \mathrm{hr}$ に対し徐放 錠群の約 $10 \mathrm{hr}$ といくらかの延長が見られる. 力 プセル剤の半減期は, 通常 4 $8 \mathrm{hr}$ といわれてお

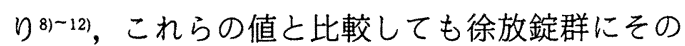
特性が見られた。徐放錠群の中では各錠剤間に差 は見られず，製剤特性が全般にわたって同等に表 れていることがわかる.

半減期の中には薬物の消失効果ばかりでなく分 布効果も含まれているので，その効果を臨床的に 見ようとする場合, その薬物の血中濃度維持時間 の検討が有効と考えられる.

本剤の最低有効血中濃度については諸家の報告 が見られるが(3114)，それらの測定法は蛍光法 ${ }^{15)}$, ガスクロマトグラフィー法 ${ }^{1617}$, 高速液体クロマ トグラフィー法 (HPLC) 等で, いずれも disopyramide 本体およびその代謝物の total として測 定されている（但し，HPLCについては最近分 離測定が可能となっている). 今回, 我々は被験 者の安全性を第一に考虑したため, 多量の検体を 短時間で処理することが要求された。そこで，血 中濃度測定結果を速やかに知ることが出来る EMIT 法を利用した。しかしこの方法による結
果は代謝物を除く disopyramide 本体のみを測定 した值であり, total 量の約 1 割を占める代謝物 は除外されている．Tab. 3 のように最低有効血 中濃度を設定した場合, 従来の $100 \mathrm{mg}$ カプセル と $150 \mathrm{mg}$ 錠とでは 1 日投与量が同じであるのに， $1.0 \mu \mathrm{g} / \mathrm{ml}$ 維持時間では $16.8 \mathrm{hr}$ と $18.8 \mathrm{hr}$ で 2 $\mathrm{hr}$ の差を生じている．また，これは、 $1.2 \mu \mathrm{g} / \mathrm{ml}$ 維持時間にするとより顕著であり, $100 \mathrm{mg}$ カプ セルの $6 \mathrm{hr}$ に比べ $150 \mathrm{mg}$ 錠の $10.4 \mathrm{hr}$ と約 $4 \mathrm{hr}$ (1.7 倍) の延長を認め, 徐放剂の特性はここに 顕著に認められている. 一方, $1.4 \mu \mathrm{g} / \mathrm{ml}$ 維持時 間では $100 \mathrm{mg}$ カプセルの $1.5 \mathrm{hr}$ に対し $150 \mathrm{mg}$ 徐放錠は $0 \mathrm{hr}$ で，最高血中濃度の点から見ると 従来の $100 \mathrm{mg}$ カプセルが優れているようである.

$200 \mathrm{mg}$ の 1 週間連続投与の結果を見てみると， 投与開始から 4 - 5 回目 (3日目) 以降に steady stateになり，この状態では $1.2 \mu \mathrm{g} / \mathrm{ml}$ 維持時間 は $24 \mathrm{hr}$ 全てを満たしており,また $1.4 \mu \mathrm{g} / \mathrm{ml} て ゙$ は約 $20 \mathrm{hr}$ 程度の維持が可能となっている．つま り，連続投与することにより薬剤の効果はより明 確になりその有用性を高めるものと思われる.

先に示したように，連続投与による steady state に至るまでの期間は服用から 3 日間程度で あることがわかる。一般的には steady state 到達 期間は半減期の 5 10 倍を要するとされており, 徐放錠の半減期約 $10 \mathrm{hr}$ からみて今回の結果は妥 当なものと思われる. Steady state における最高 血中濃度および最低血中濃度は各々約 $2.1 \mu \mathrm{g} / \mathrm{ml}$, 約 $1.2 \mu \mathrm{g} / \mathrm{ml}$ であった. 1 週間連続投与による自 覚症状および理学所見的な副作用は見られず，ま た臨木検查值にも著変は見られないことから安全 性の確認はできたものと思われる.

尿中排泄については代謝物の排泄をも確認する ためHPLC 法により実施した. 測定は 3 回連続 投与のみで実施しており採尿時間が短かったため 充分なことは言えないが, 排泄量が徐々に増加し ていく傾向を示しており，36 hr までに約 30\%程 度が排泄されていることがわかる。一般に尿中排 泄は disopyramide 経口投与の場合 $70 \%$ 程度と知 られているが，これは０からのとした時のもので 
ある. 今回の数值 $30 \%$ は 0 から $36 \mathrm{hr}$ の排泄をみ たものであり単純な比較は難しい. しかし steady stateではこれに近い排泄量を示すと予想 され，この差が体内に貯留し飽和状態を作ると思 われる。

理論曲線から予想される分布容績は約 1001 程 度であり, disopyramide は体内の隅々までいき わたる可能性を有している. 1 週間連続投与時の 血中濃度推移から, 飽和状態をつくり steady state に至るのに約 3 日程かかることがわかる.

1 日投与量が同量の $100 \mathrm{mg}$ カプセルと $150 \mathrm{mg}$ 徐放錠とでは，0～ $24 \mathrm{hr}$ の尿排泄が $33.5 \%$ と $28.9 \%$ で体内貯留は徐放錠が優れている.

以上から，この徐放錠は pharmacokinetics 的 検討からも充分に徐放効果を有しており，長期連 用にも耐えうる安全性を有し，使い易い薬剤と結 論される.

\section{結 語}

徐放性製剂である disopyramide phosphate の 日本人健常人における Phase I Studyをdiso pyramide カプセルを対照薬として実施し，本剤 の安全性ならびに pharmacokinetics 的検討を 行った.

試験方法は cross-over 法にて DP の $150 \mathrm{mg}$ 錠, $200 \mathrm{mg}$ 錠, $250 \mathrm{mg}$ 錠および disopyramide $100 \mathrm{mg}$ カプセルの 3 回連続投与を実施し, その 後被験者を代えて $200 \mathrm{mg}$ 錠 1 週間連続投与試験 を実施した。

1 )自覚症状には全く異常は認められず,血圧・ 脈拍・体温・心電図にも薬剤に係ると思われる臨 床上有意な変化はみられなかった。

2 ) 血液学的検查, 生化学検査, 尿検査では一 部で正常域内でのわずかな変動を認めた.

3 ) 最高血中濃度は $100 \mathrm{mg}$ カプセル 1 Cap. 投 与後 $2 \mathrm{hr}$, 徐放錠では $4 \sim 6 \mathrm{hr}$, 徐放錠連続投与 時では $4 \mathrm{hr}$ に認められた。

4 ) 徐放錠 3 回連続投与による尿中排泄はカプ セル剤より遅く, steady stateにいたるまでは体 内貯溜のため, その程度は低下していた。
5 ） $200 \mathrm{mg}$ 錠 1 週間連続投与により steady state に至るのに約 3 日を要した.

以上の結果から DP $(150,200,250 \mathrm{mg}$ 錠) の日本人健常人での血中濃度推移および安全性が 確認され, Phase II Study testへの移行に支障 がないものと判定した. なお，至適投与量につい ては1日 300〜400 mg と思われるが，その結論は Phase II Study test の結果に委ねる.

\section{文 献}

1) Pape, B.E. : Enzyme immunoassay of disopyramide in serum. Clin. Chem., $27: 2038-2040$ (1981).

2) Singh, B. N. and Hanswirth, O. : Comparative mechanisms of action of antiarrhythmic drugs. Am. Heart J.,87:367-382 (1974).

3) Vaugham Willams, E. M. : In Sandie, E., Flensted-Jensen, E. C.., and Olesen, K. H.(Eds.). Classification of antiarrhythmic drug. Simposium on cardiac arrhythmias. Sweden, Astra, A. B., p. 499 (1970).

4) 館田邦彦, 小原剛, 柴田淳一ほか：Rythmodan の長期使用の経験. 薬理と治療, 9 : 169-176 (1981).

5) 木村栄一, 真島三郎, 田中恒男: Disopyramide その抗不整脈効果の多施設二重盲検試験 による判定. 心臓, 10：570-576 (1978).

6) 木村栄一, 春見建一, 安井昭二ほか：発作性頻 拍および一過性心房細動に対する Disopyramide の予防効果. 臨床と研究, $58: 237-246$ (1981).

7）日本ルセル(侏)資料：抗不整脈剂 Disopyramide phosphate (125 mg 錠) のホルター心電図によ る臨床効果の検討.

8) Karim, A. : The pharmacokinetics of norpace. Angiology, 26 : Suppl. $1: 85-98$ (1970).

9) Hinderling, P. H. and Garett, E. R. : Pharmacokinetics of the antiarrhythmic disopyramide in healthy humans. J. Pharmacokin. Biopharm., 4:199-230 (1976).

10) Dubetz, D. K., Brawn, N. N., Hooser, W. D. et al. : Disopyramide pharmacokinetics and bioavailability. Br. J. Clin. Pharmac.,6 : 279-281 (1978).

11) Bryson, S. M., Whiting, B., Lawrence, J. R. : Disopyramide serum and pharmacologic effect kinetics applied to the assessment of bioavailability. Br. J. Clin. Pharmacol., 6,409-419 
(1978).

12）楠岡英雄, 井上通敏, 堀正三ほか：Disopyramide の経口および静脈内投与における Pharmacokinetics. 臨床薬理, $11: 49-57$ (1980).

13) Mizgala, H. F. and Huvelle, P. R. : Acute termination of cardiac arrhythmias with in travenous disopyramide. J. Int. Med. Res., 1 : 82-85 (1976).

14) Niarchos, A.P.: Disopyramide : Serum level and arrhythmia conversion. Am. Heart J. 92 : 57-64 (1976).

15) Gupta, R. N., Eng, F. and Lewis, D. : Fluoresc- ence photometric determination of disopyramide and mono-N-dealkylated disopyramide in plasma after separation by thin-layer chromatography. Anal. Chem., 51:455-458 (1979).

16) E. N, and Reid, P. R. : Simplified method for the measurement of disopyramide in plasma. J. Chronato.,178: 571-574 (1979).

17) Aito, M. L. : Simultaneous determination of disopyramide and its mono-N-dealkylated metabolite in plasma by gas-liquid chromatography. J. Chnomato.,164: 515-520 (1979). 


\title{
Diazepam 静注時の薬理作用に及ぼす投与時 刻の影響
}

\author{
長 井啓 介* 渡 部 博 和* 中 野 重 行* \\ （受付：1984年 2 月27日）
}

\author{
Time-of-day Effect of Intravenous Diazepam on Pharmacologic \\ Actions in Man
}

\author{
Keisuke NAGAI* Hirokazu WATANABE* and Shigeyuki NAKANO* \\ Department of Pharmacology, Ehime University, School of Medicine
}

Our group previously reported the time-of-day effect of oral administration on diazepam kinetics and its sedative action in healthy men. In these studies, it has been suggested that the absorption rate of diazempam from the gastrointestinal tract is faster in morning dosing than in evening dosing. The present study was performed to elucidate the mechanism of time-of-day effect on diazepam kinetics and dynamics, administering $5 \mathrm{mg}$ diazepam (Cercine ${ }^{\circledR}$ injectable solution) intravenously under the same experimental conditions as the oral dose study described above. Eight healthy volunteers participated in the study. The subjects received a 5-mg dose of diazepam intravenously at $9: 30$ a. m. and after a 2 -wk interval, at $9: 30$ p. m., in a randomly assigned cross-over study. Meals were standardized in order to fit the subjects' usual meal amount. Plasma diazempam concentrations were determined by gas chromatography (ECD). Changes in subjective feelings such as "mentally slow," "feeble," "clumsy", and "lethargic" were more marked in the morning trial at $0.5 \mathrm{hr}$ after injection. More marked sedative effects were demonstrated in the morning trial by using the digit symbol substitution test and the continuous number addition test. Mean $( \pm S D)$ total diazepam concentrations in plasma in the morning trial vs in the evening trial were : $218( \pm 15)$ vs 192 ( \pm 12) $\mathrm{ng} / \mathrm{ml}$ at $0.5 \mathrm{hr}$ after drug administration $(0.05<\mathrm{P}<0.1) ; 164( \pm 39)$ vs 132 ( \pm 16) $\mathrm{ng} / \mathrm{ml}$ at $1 \mathrm{hr}$ after injection $(\mathrm{P}<0.05)$. The results suggest that there exists

\footnotetext{
* 愛媛大学医学部薬理学教室 昰791-02 愛媛県温泉郡重信町志津川
} 
time-of-day effect of intravenous injection with diazepam injectable solution on sedative actions and kinetics, which may be clinically important in some situations. In addition, the time-dependent kinetics of diazepam after oral dosing cannot be explained only by the absorption rate from the gastrointestinal tract, since intravenous administration of diazepam did not eliminate the difference in total plasma diazepam concentrations between morning and evening dosing at $0.5 \mathrm{hr}$ and $1 \mathrm{hr}$ after injection.

Key words : diazepam injectable solution, chronopharmacology, time-of-day effect, circadian rhythm, visual analogue self-rating scale

\section{緒 言}

近年, 種々の薬物に対する生体の反応性に投与 時刻によって差異が認められるという所見が，主 として動物実験で報告され注目されている。この 分野は, 時間薬理学 (chronopharmacology) と称 され，実験動物のみならず，ヒトにおいても認め られる現象であることが明らかにされている1。

Reinberg ${ }^{2)}$ は, 時間薬理学の研究においては, 薬物に 対する生体側の感受性のリズム (chronesthesy), 薬物動態のリズム (chronopharmacokinetics), ならびに薬物の効果のリズム (chronergy)の それぞれの面から検討する必要性のあることを 指摘している. 時間薬理学の考え方を更に発展さ せ, 薬物の投与量のみならず投与時刻をも, 各個 人の生体リズムに合わせて最も適した形で選択す ることにより，合理的な薬物療法を志向すること が本研究の目的である.

これまでの研究において, diazepam 経口投与 時には, 朝内服時は晚内服時に比較して鎮静作用 がより強く出現し, 内服後初期 $(0.5 \sim 1 \mathrm{hr})$ に おいて血漿中総 diazepam 濃度が有意に高い所見 を認めた ${ }^{3)}$.この結果から, 薬物動態と薬理作用 の出現様式が投与時刻により異なる所見が生ずる 原因の 1 つに, 消化管からの吸収速度が関与する ことが考えられだ).

そこで本研究では, 消化管からの吸収の要因を 除外するために, 臨床で普通使用されている diazepam 注射液の静脈内投与を行った場合にも， 朝と晚という投与時刻間で, 薬理作用の出現様式
に差異が存在するか否かを検討した.

\section{対象および方法}

\section{1. 対象}

健康な愛媛大学医学部男子学生 volunteers 8 名 を対象とした。年齢は $25 \pm 1$ 歳 (Mean $\pm S D)$, 体重は $65 \pm 6 \mathrm{~kg}$ で, 身体的ならびに心理的に特 記すべき所見を認めず, 向精神薬内服の既往がな いことを条件とした. 被験者には研究の趣旨と手 続きについて十分な説明を行い, 試験参加に関す る同意を文書により得た.

\section{2. 測定項目}

(1)自覚症状

16 項目の自覚症状からなる Norris ${ }^{4}$ の $100 \mathrm{~mm}$ visual analogue self-rating scale 当教室で訳 し使用した. 自覚症状の動きは, 薬物投与前から の変化量で測定した.

(2)数字記号置き換え試験（Digit symbol substitution test)

ランダムに並べられた数字の下に，あらかじめ対 応の決められた図形を置き換えて記入するという 作業を, 集中して $2 \mathrm{~min}$ 間試行させた. 薬物投与 前から投与後にかけての正答数の変化量を測定 し，鎮静作用の指標とした。

(3)連続加算試験 (Continuous number addition test)

内田・クレペリンテスト点参考にして，3 3 ら 9 の数字をランダムに並べ, かつ同じ数字が続 かないようにして, 縦 18 列, 横 36 列の数字から なるテスト用紙を作製した。左右に隣り合う数字 
を加算し，その下 1 桁を記入するという連続加算 作業を, 集中して $3 \mathrm{~min}$ 間試行させた. 薬物投与 前から投与後にかけての正答数の変化量を測定 し，鎮静作用の指標とした.

(4)血漿中総 diazepam 濃度

血漿中総 diazepam および N-desmethyldiazepam 濃度は, de Silva らの方法6に従ってガスク ロマトグラフィー（ECD）を用いて定量した。 その際, 内部標準物質として medazepam を用い て, ピークの高さの比から求めた検量線より, diazepam および N-desmethyldiazepam 濃度を決 定した.

\section{3. 実験手続き}

実験は, すべて愛媛大学医学部薬理学教室の比 較的静かな研究室で, 昭和 57 年 7 月 3 日および 4 日,さらに 2 週間の washout 期間をおいて 7 月 17 日および 18 日に行った。被験者全員に簡易べ ッドを用意し, diazepam $5 \mathrm{mg}$ (Cercine ${ }^{\circledR}$ 注射 液として $1 \mathrm{ml}$ ：以下 diazepam 注射液と記す）を $1 \mathrm{~min}$ 間かけて, 一定速度で静脈内投与した. 投 与時刻は, 朝 $9: 30$, または, 夜 $21: 30$ とした。 投与時刻に関して cross-over design を採用し, 朝投与 $\rightarrow$ 夜投与を行う者 4 名と, 夜投与 $\rightarrow$ 朝投与 を行う者 4 名に，ランダムに割りあてた。食事条 件に関しては, 被験者の平素の食事量に近いもの を調製して用意し, 朝投与時には, $8: 00$ から 8 $: 15$ の間に, 夜投与時には, $18: 00$ から $18: 30$ の間にとらせた. 自覚症状チェックリスト, 2 $\min$ 間の数字記号置き換え試験, および $3 \mathrm{~min}$ 間 の連続加算試験を薬物投与前, 投与後 $0.5 \mathrm{hr}$ お よび $1 \mathrm{hr}$ に行った. 採血は, 薬物投与前, 投与 後 $0.5 \mathrm{hr}$ および $1 \mathrm{hr}$ に行った.

\section{4. 統計解析}

自覚症状, 数字記号置き換え試験, 連続加算試 験に関する diazepam 注射液投与前から投与後に かけての変化量および血漿中総 diazepam 濃度の 投与時刻間の比較には, paired t-test を使用した。

\section{結 果}

1. Diazepam 注射液の薬理作用に及ぼす投与
Tab. 1 Changes in Subjective Feelings at $0.5 \mathrm{hr}$ after an Intravenous Administration of $5 \mathrm{mg}$ Diazepam

\begin{tabular}{|c|c|c|c|}
\hline \multirow{2}{*}{$\begin{array}{l}\text { Subjective feelings measured } \\
\text { by } 100 \mathrm{~mm} \text { visual analogue } \\
\text { self-rating scale }\end{array}$} & \multicolumn{3}{|c|}{ Change from pre-drug level ( $\mathrm{mm})$} \\
\hline & $\begin{array}{r}\text { Morning triale } \\
(\mathrm{N}=8)\end{array}$ & $\begin{array}{r}\text { Evening trial } \\
(\mathrm{N}=8)\end{array}$ & $\begin{array}{l}\text { Statistical } \\
\text { significance* }\end{array}$ \\
\hline $\begin{array}{l}\text { Mentally slow vs Quick witted } \\
(+=\text { more mentally slow })\end{array}$ & $27.3 \pm 8.7$ & $15.5 \pm 11.6$ & $p<0.01$ \\
\hline $\begin{array}{l}\text { Oreamy vs Attentive } \\
(+=\text { more dreamy })\end{array}$ & $21.3 \pm 14.9$ & $8.6 \pm 6.4$ & $p<0.05$ \\
\hline $\begin{array}{l}\text { Relaxed vs Tense } \\
(+=\text { more relaxed })\end{array}$ & $10.3 \pm 12.9$ & $17.0 \pm 14.2$ & $0.05<p<0.1$ \\
\hline $\begin{array}{l}\text { Feeble vs Strong } \\
(+=\text { more feeble })\end{array}$ & $27.5 \pm 10.6$ & $20.8 \pm 10.4$ & $0.05<p<0.1$ \\
\hline $\begin{array}{l}\text { Clumsy vs Well co-ordinated } \\
(+=\text { more clumsy })\end{array}$ & $30.6 \pm 9.9$ & $23.6 \pm 9.8$ & $p<0.05$ \\
\hline $\begin{array}{l}\text { Lethargic vs Energetic } \\
(+=\text { more lethargic })\end{array}$ & $26.1 \pm 8.4$ & $10.3 \pm 18.4$ & $p<0.05$ \\
\hline
\end{tabular}

Values represent mean \pm S. D.

*Statistical evaluation by paired t-test

\section{時刻の影響}

Diazepam 注射液投与前に行った自覚症状, 数 字記号置き換え試験, 連続加算試験の成績には, いずれも差を認めなかった。

\section{a . 自覚症状の変化}

自己評価尺度 (self-rating scale) の 16 項目の うち 6 項目において, 投与時刻による差異が認め られた (Tab. 1). そのうちわけは, 鎮静作用を 示唆する症状が 2 項目 (「頭の働きがにぶい」,「ぼ んやりして夢見ごこちだ」), 抗不安作用を示唆す る症状が 1 項目 (「リラックスしている」), 筋弛 緩作用を示唆する症状が 3 項目（「力がぬけてい る」,「動作がぎこちない」，「体がだるい」）であっ た. 鎮静作用を示唆すると考えられる「頭の働き がにぶい」(mentally slow),「ぼんやりして夢見 ごこちだ」(dreamy) といった自覚症状の強さを 投与時刻間で比較すると, 朝の方が晚に比べて有 意に強いことが認められた (Fig. 1). 同様の所 見は，筋弛緩作用を示唆する項目である「力がぬ けている」(feeble), 「動作がぎこちない」 (clumsy),「体がだるい」(lethargic) でも認め られた (Fig. 2). しかし, 抗不安作用を示唆す る症状である「リラックスしている」(relaxed) に関しては, 晚投与時には投与後 $1 \mathrm{hr}$ にも依然 として作用が持続していた（Fig.1）.

また鎮静作用, 筋弛緩作用を示唆する項目ば, 
A)
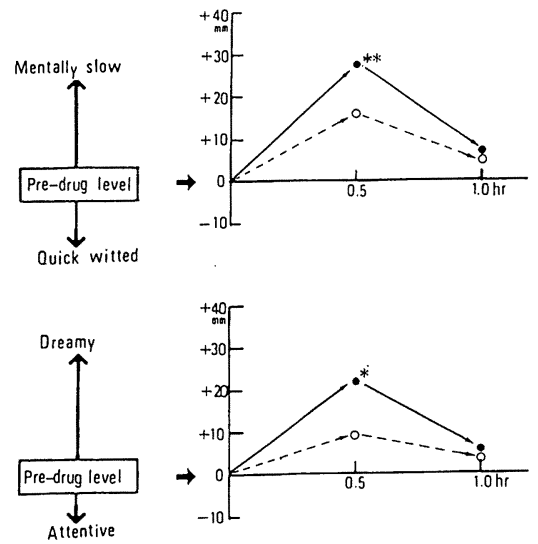

B)

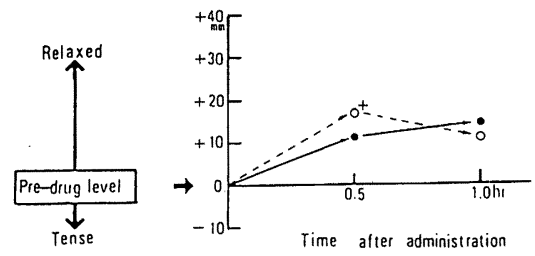

Fig. 1 Time-of-day effect of an intravenous administration with $5 \mathrm{mg}$ diazepam on subjective feeling. A : items suggesting diazepam-induced sedative action, $B$ : item suggesting antianxiety action of diazepam. - : morning trial (administration time : $9: 30), \bigcirc \cdots \cdots \bigcirc$ : evening trial (administration time $: 21: 30$ ). $+\mathrm{P}<0.10,{ }^{*} \mathrm{P}<0.05,{ }^{* *} \mathrm{P}<0.01$ : significantly different between two trials (paired t-test, two-tailed)

いずれも diazepam 注射液静注後 $0.5 \mathrm{hr}$ に強く出 現し，1 hrには投薬前のレベルにほぼ回復した。

b. 数字記号置き換え試験

Diazepam 注射液静注後には, 数字記号置き換 え試験の正答数の投与前から投与後にかけての変 化量は, 晚投与時には, 投与後 $0.5 \mathrm{hr}$ から $1 \mathrm{hr}$ にかけて次第に増加した．朝投与時には正答数の 変化量は，投与後 $0.5 \mathrm{hr}$ に一時的に低下傾向を 示したが， $1 \mathrm{hr}$ に増加した．投与時刻間で比較す ると，投与後 $1 \mathrm{hr}$ の成績が朝投与時に有意に劣っ ていた（P<0.01，Tab. 2).
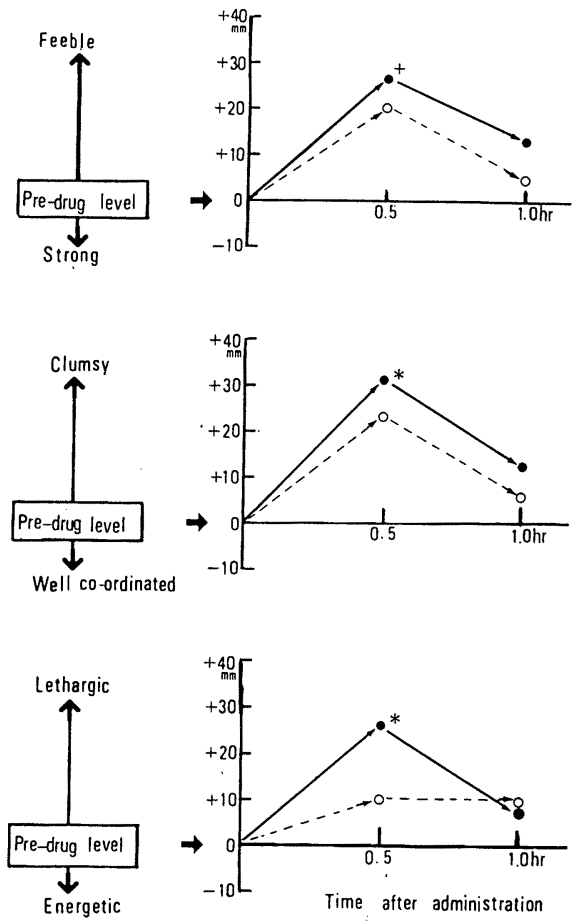

Fig. 2 Time-of-day effect of an intravenous administration with $5 \mathrm{mg}$ diazepam on subjective feeling. Items suggesting diazepam-muscle relaxant action. - morning trial (administration time $: 9: 30), \bigcirc \cdots \cdots$ : evening trial (administration time $: 21: 30) .{ }^{+} \mathrm{P}<0.10,{ }^{*} \mathrm{P}<0.05:$ significantly different between two trials (paired t-test, two-tailed)

投与後 $1 . h r$ の成績を個人別に投与時刻間で比 較してFig. 3 に示した. 数字記号置き換え試験 の成績には, 朝投与時と晚投与時の間に正の相関 を認めた（ $\mathrm{r}=0.615$, Fig. 3).

\section{c. 連続加算試験}

Deazepam 注射液静注後には, 連続加算試験の 正答数の投与前からの変化量は, 晚投与時には, $0.5 \mathrm{hr}$ から $1 \mathrm{hr}$ にかけて次第に増加した（Fig. 4). 一方, 朝投与時には, 投与後 $0.5 \mathrm{hr}$ に正答 数が一時的に減少し， $1 \mathrm{hr}$ には，投与前のレベル にほぼ回復した（Fig. 4). 投与後 $0.5 \mathrm{hr}$ および 
Tab. 2 Change of Correct Reponse in Performance Tests from Pre-drug Level after an Intravenous Dose of 5 mg Diazepam

A ) Digit symbol substitution test

B ) Continuous number addition test

\begin{tabular}{cccc}
\hline $\begin{array}{c}\text { Time after administration } \\
(\mathrm{hr})\end{array}$ & $\begin{array}{c}\text { Morning trial } \\
(\mathrm{N}=8)\end{array}$ & $\begin{array}{c}\text { Evening trial } \\
(\mathrm{N}=8)\end{array}$ & $\begin{array}{c}\text { Statistical } \\
\text { significance* }\end{array}$ \\
\hline 0.5 & $-1 \pm 6$ & $3 \pm 6$ & N.S. \\
\hline 1.0 & $5 \pm 5$ & $11 \pm 5$ & $P<0.01$ \\
\hline
\end{tabular}

B) Continuous number addition test

\begin{tabular}{cccc}
\hline Time after administration & $\begin{array}{c}\text { Morning trial } \\
(\mathrm{hr})\end{array}$ & $\begin{array}{c}\text { Evening trial } \\
(\mathrm{N}=8)\end{array}$ & $\begin{array}{c}\text { Statistical } \\
\text { significance* }\end{array}$ \\
\hline 0.5 & $-8 \pm 16$ & $8 \pm 9$ & $\mathrm{p}<0.05$ \\
\hline 1.0 & $0 \pm 16$ & $13 \pm 14$ & $\mathrm{p}<0.05$ \\
\hline
\end{tabular}

Values represent mean \pm S.D.

* Statistical evaluation by paired $t$ t-test

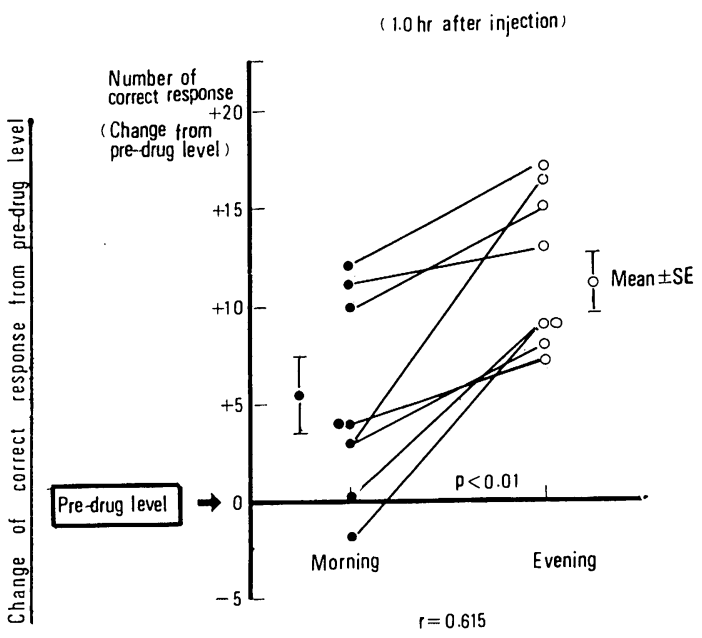

Fig. 3 Interindividual and intraindividual variation of digit symbol substitution test at $1 \mathrm{hr}$ after an intravenous administration with $5 \mathrm{mg}$ diazepam.

$1 \mathrm{hr}$ のいずれにおいても，朝投与時には晚投与時 に比較して正答数が有意に少なかった（いずれも $\mathrm{P}<0.05$, Tab. 2).

2. 血漿中総 diazepam 濃度に関する投与時刻 による比較

Diazepam 注射液静注後 $0.5 \mathrm{hr}$ の血漿中総 dia-

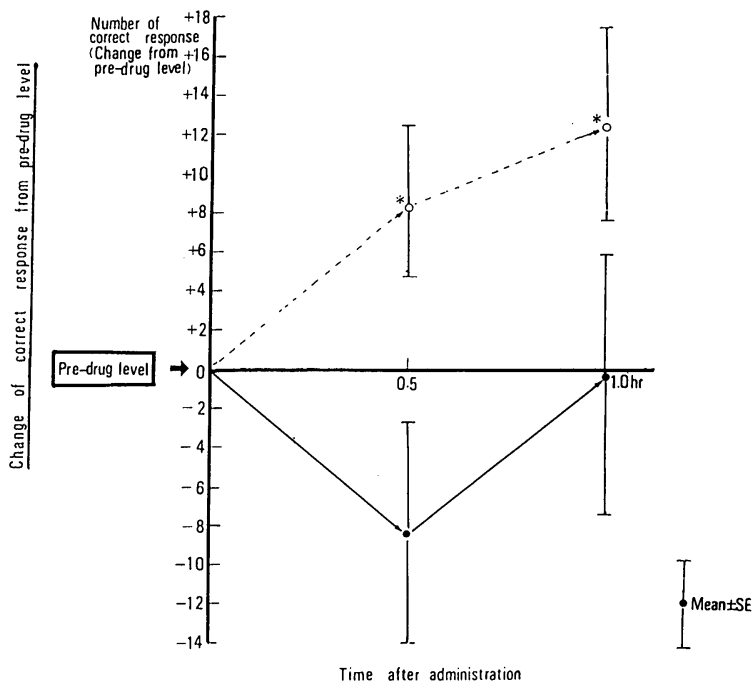

Fig. 4 Continuous number addition test after an intravenous administration with $5 \mathrm{mg}$ diazepam. - - morning trial (administration time : 9 : 30), $\bigcirc \cdots \cdots \bigcirc$ : evening trial (ad. ministration time : $21: 30) . * \mathrm{P}<$ 0.05 : significantly different between two trials (paired t-test, two-tailed).

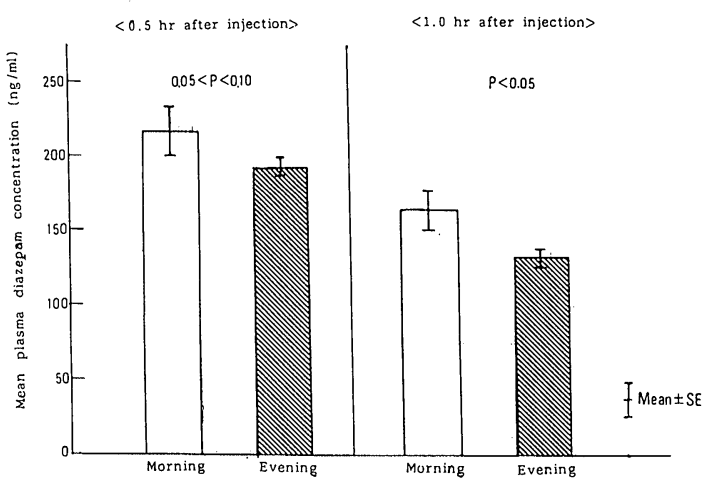

Fig. 5 Mean plasma diazepam concentrations after an intravenous administration with $5 \mathrm{mg}$ diazepam. Statistical evaluation by paired t-test(two-tailed).

zepam 濃度は, 朝投与時には $218 \pm 15 \mathrm{ng} / \mathrm{ml}$, 晚 投与時には $192 \pm 12 \mathrm{ng} / \mathrm{ml}, 1 \mathrm{hr}$ の血漿中総 diazepam 濃度は, 朝投与時には $164 \pm 39 \mathrm{ng} / \mathrm{ml}$, 晚 
投与時には $132 \pm 16 \mathrm{ng} / \mathrm{ml}$ であり，朝投与時には 晚投与時に比較して高いことが認められた $(0.5$ hr : $0.05<\mathrm{P}<0.1,1 \mathrm{hr}: \mathrm{P}<0.05$, Fig. 5). な お, diazepam の主たる活性代謝産物である Ndesmethyldiazepam は, 静注後 $0.5 \mathrm{hr}$ およ゙ $1 \mathrm{hr}$ には検出されなかった（検出限界 $10 \mathrm{ng} / \mathrm{ml}$ ).

\section{考 察}

Diazepam $5 \mathrm{mg}$ を経口投与した際には, 朝投与 時には晚投与時に比較して鎮静作用が強く出現 し,この時同時に最高血漿中総 diazepam 濃度 $\left(C_{\text {max }}\right)$ が高く, $C_{\text {max }}$ に到達するのに要する時 間 $\left(t_{\max }\right)$ が短いことを, 私共はすでに報告して いる7).このような吸収相における薬物動態の投 与時刻における差異は, 一般に吸収速度の差異と して理解されることが多い。しかし，薬物投与後 初期のこの時間帯にみられる血漿中総薬物濃度 は, 吸収以外の要因も関与している可能性がある. そこで本研究では, 投与時刻による消化管からの 吸収の影響を除く目的で, diazepam 注射液を直 接静脈内に単回投与し，この時の生体側の反応性 が, 朝と晚で異なるか否かを, 自覚症状の変化,

精神作業能率を指標にして検討した。 なお，本試 験で使用した diazepam 注射液には, diazepam 以外に有機溶媒を含有しており，この溶媒 $1 \mathrm{ml}$ の静注により生ずる作用を無視することはできな い. 従って, diazepam 錠経口投与時の資料と直 接対比して論ずることには慎重でなければならな W.

朝投与時には晚投与時に比較して, diazepam 注射液静注後 $0.5 \mathrm{hr}$ に鎮静作用を示唆する所見 が有意に強く出現し，1 hrにはほほぼ静注前のレ ベルに復した. 筋弛緩作用を示唆する自覚症状で も，同様の所見を認めた．これらの所見から diazepam 注射液による薬理作用の出現のしかたは, 朝之晚という投与時刻間で異なり, 朝投与時には, より強く出現することがわかる. この時, 血漿中 diazepam 濃度にも同じ時間帯で投与時刻により 差異を認め, 朝投与時に高い.このことから， diazepam 注射液の薬理作用の出現のしかたが投
与時刻により異なるという現象の生ずるメカニズ ムとして次のことが考えられる.すなわち, 作用 点の存在する中枢神経系の diazepam 注射液に対 する感受性だけでなく, 静脈内から作用部位に薬 物が到達するまでの diazepam の薬物動態に, 朝 と晚で差異があるという可能性である.

次に血漿中総 diazepam 濃度の投与時刻による 差異について考えてみたい. 前述したごとく， diazepam の経口投与時には，朝投与時には晚投 与時に比較して, 吸収相における血漿中総 diazepam 濃度が有意に高い。また, $C_{\max }$ がより高く, $t_{\max }$ は短い. しかし, 血中除去相半減期 $\left(\mathrm{t}_{1 / 2} \beta\right)$ と濃度一時間曲線下面積 (AUC) には差を認め ていない7).これらの所見から diazepam の消化 管からの吸収速度に投与時刻による差異の存在す る可能性が示唆される. Diazepam の経口投与時 における消化管からの吸収速度は, 胃の通過時間 の変化により影響を受ける8). また, 胃内にとど まっている食事量も薬物の胃の通過時間を変化さ せることを介して吸収に影響を与える9. しかし， 食事と胃通過時間の影響を除く目的で, 絶食条件 下で経口投与または直接十二指腸内に投与した場 合にも, diazepam の薬物動態に及ぼす投与時刻 による差は消失しない(10)11). 従って, 経口投与時 における diazepam の薬物動態に及ぼす投与時刻 の影響は，摂食量や胃通過時間の朝と晚における 差のみでは説明が困難である.

さらに, 本研究では, 消化管からの吸収の要因 を除くために diazepam 注射液の静脈内投与を 行ったが, 薬物動態に及ぼす投与時刻による影響

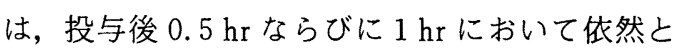
して存在した，血漿中総 diazepam 濃度に, 投与 時刻による差の認められた投与後 $0.5 \mathrm{hr}, 1 \mathrm{hr} に$ は, diazepam の主たる活性代謝産物である Ndesmethyldiazepam は, 血漿中に検出されてい ない. Diazepam は, 主として肝蔵における代謝 により除去されるが, その速度は遅く, $\mathrm{t}_{1 / 2} \beta$ の長 い薬物であることを考えると, diazepam 静注後 の初期に認められた血漿中総 diazepam 濃度の差 には，代謝の影響よりも diazepam の生体内にお 
ける分布速度の投与時刻による差異が関与してい る可能性が強い。

一般に薬物の血中から組織への分布は，組織へ の分配速度, 薬物の膜透過性ならびに蛋白結合能 などの要因によって規定される ${ }^{12)}$. Diazepam の 血漿蛋白結合率は，97-99\% と高く13/14115)16)，血漿 蛋白結合率のわずかな変化によっても体内分布が 影響を受ける可能性がある. 事実, $9 \mathrm{hr}$ の絶食条 件下で diazepam 注射液の静脈内投与を行い，投 与後 $0.5 \mathrm{hr}$ の血漿中 diazepam の血漿中蛋白結合 率が, 朝投与時に晚投与時より有意に高く, その 結果同じ時点における血漿中総 diazepam 濃度に 差を生ずるという所見を私共はすでに報告してい る ${ }^{17}$. 本研究は, 通常の食生活に近い摂食条件下 で行ったものであるが, 投与後 $0.5 \mathrm{hr}$ および 1 hrにみられた血漿中総 diazepam 濃度の投与時刻 による差には, 同様のメカニズムを介する分布速 度の差が関与していることが推察される.このよ うな現象の生ずる背景には, 生体機能や種々の生 体成分の日周リズムによる変動が関与しているも のと思われるが詳細は不明である。

自覚症状, 数字記号置き換え試験, 連続加算試 験のいずれにおいても, diazepam 注射液静注後 $0.5 \mathrm{hr}$ に, 朝投与時に鎮静作用が強く出現し, 1 hrには，静注前のレベルに復した，従って，diazepam 注射液の静注による鎖静作用は, 一過性 のものであり，回復は非常に速い. Benzodiazepine 系抗不安薬では, 単回投与時に生体内薬物 濃度の時間に伴う減少の速さに比較して, 鎮静作 用が急速に回復することから，この現象はbenzodiazepine 系抗不安薬に対する中枢神経系の急 性耐性（acute tolerence）または単回投与耐性 (single dose tolerance) と呼ばれている ${ }^{1819}$. Diazepam 注射液静注後の鎮静作用が比較的速く 回復するのもこのような急性耐性あるいは単回投 与耐性を反映しているのかもしれない。しかし， このような所見は抗不安作用を示唆する自覚症状 では認められなかった。

朝と晚という投与時刻により， diazepam 注射 液の静注による作用に差が認めらめたのは，鎮静
作用ならびに筋弛緩作用であり，抗不安作用には 差を認めなかった. Diazepam を抗不安薬として 臨床で使用する場合には，鎮静作用や筋弛緩作用 はいわゆる副作用としてとりあげられる症状であ る. 考察の冒頭にも記したように, diazepam と diazepam 注射液を同一に論ずることはできない が, この所見の意義を臨床的立場から考えてみる と, 抗不安薬として diazepam を投与した時には 出現頻度の比較的高い睡気, 倦怠感, ふらつき, 脱力感といった症状の出現のしかたが，投与時刻 によって異なりうるのであれば，より適切な投与 時刻の設定によりこれら副作用を減少させうる可 能性があるのかもしれない，健常人により得られ たこのような成績が精神神経症状を有する患者の 薬物療法の際にもそのまま認められるのか否か, あるいは認められるとしてもどのような変容を受 けるかについては, 時間薬理学の視点に立った臨 床研究の結果を待たねばならない.

次に自覚症状の測定法に関して少し触れてみた い.ここで言う自覚症状とは, 正確には被験者の

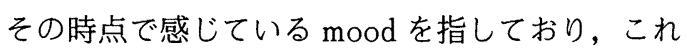
を計量的に表現したものである. Aitken ら ${ }^{20)}$, Hayes ら ${ }^{211}$ は, 自覚症状を測定する際に, category scale では同一の言葉を提示しても被験者の 体験している自覚症状との相同性があるとは言え ず, category size が, 被験者間で同一であるか どうかもわからないとして analogue scaleを推 めている. Analogue scale の利点としては, (1) 同一個人内の自覚症状の変化を比較するのに感度 がよい, (2)統計処理上, ノンパラメトリック法, パラメトリック法のいずれも適用できる, (3)被験 者にとってわかりやすい, (4)短い時間でチェック できる，(5)モチベーションがつけやすい，などが あげられている2022). 薬物による自覚症状の変化 の測定にも応用されており ${ }^{423324)}$, 私共も, 本研究 における自覚症状の測定に Norris の 16 項目から なる $100 \mathrm{~mm}$ visual analogue self-rating scale (16 linear scales $)^{4)}$ を使用したが，上記の利点を 同様に認めた。 


\section{結 語}

8 名の健康な学生 volunteer 対象にして diazepam 注射液（Cercine ${ }^{\circledR} 5 \mathrm{mg}$ ) を静脈内投与 した場合に, 薬理作用の出現のしかたに, 朝と晚 という投与時刻による影響が認められるか否かを 検討した。Diazapam 注射液による薬理作用の出 現のしかたを, 朝の 9 時半と晚の 9 時半の 2 時点 で比較した。指標としては, 自覚症状, 数字記号 置き換え試験，連続加算試験を用いた。静注後 $0.5 \mathrm{hr}$ と $1 \mathrm{hr}$ に採血し, 血漿中総 diazepam 濃 度を測定した。投与時刻に関して, cross-over design を採用し， 2 回の trial の間に 2 週間の washout 期間を設けた. その結果は次のように要 約される.

(1) Diazepam 注射液による鎮静作用は，朝投与 時において有意に強く出現した。すなわち，自覚 症状, 数字記号置き換え試験, 連続加算試験のい ずれを指標とした場合でも認められた，同様の所 見は，筋弛緩作用を示唆する自覚症状の変化にお いても認められた. しかし，抗不安作用を示唆す る自覚症状の変化では, 投与時刻による差異は明 らかでなかった．投与時刻による差異の認められ た症状は, diazepam を抗不安薬として臨床で使 用する場合には，いずれも主として副作用として 認められる症状であった。

(2)血漿中総 diazepam 濃度は, 静注後 $0.5 \mathrm{hr}$, $1 \mathrm{hr}$ において, 朝投与時の方が, 晚投与時より 高い. Diazepam注射液の静注による薬理作用の 投与時刻による差異は, 中枢神経系の感受性の日 内変動のみならず, diazepam が作用部位に到達 するまでの体内動態の要因も少なくとも一部関与 している可能性がある.

(3)投与時刻によって薬物の作用 (diazepam 注 射液の場合には，主として副作用）の出現のしか たが異なるのであれば，副作用を最少限にしつつ 目的とする主作用を最大限に発現させるために適 切な薬物投与時刻の設定が可能になるかもしれな い.このような薬物投与法は, 個人の薬物動態学 的特性に応じて投与法を調整するという薬物療法
の個別化に加えて, 投与時刻に配慮を行うことに より，合理的な薬物投与法を一歩進めうる可能性 を示すものと言えよう.

謝辞：本論文の内容について御指導ならびに御 校閲頂いた愛媛大学医学部薬理学教室小川暢也教 授に深謝します。また，本研究の実施にあたり御 協力頂いた愛媛大学医学部学生篠山英道君ならび に被験者の皆様に感謝致します。

\section{文 献}

1) Reinberg, A. and Halberg, F.(Eds.): Chronopharmacology., Pergamon Press, pp. 403-426 (1978).

2) Reinberg, A.: Advances in human chronopharmacology. Chronobiologia., 3 : 151-166 (1976).

3）渡部博和, 中野重行, 小川暢也：Diazepam の 吸収に及ぼす投与時刻の影響. 臨床薬理, 10 ： 605-606 (1979).

4) Norris, $H .:$ The action of sedatives on brain stem oculomotor systems in man. Neuropharmacol., 10:181-191 (1971).

5) 内田勇三郎：内田クレペリン精神検査手引。 日 本精神技術研究所 (1951).

6) de Silva,J.A.F., Berkersky, I., Puglisi, C. V. et al. : Determination of 1,4-benzodiazepines and-diazepine-2-ones in blood by electroncapture gas-liquid chromatography. Anal. Chem.,48:10-19 (1976).

7) Nakano, S., Watanabe, H. and Ogawa, N. : Circadian effect on diazepam kinetics in man. Clin. Pharmacol. Ther., $27: 274$ (1980).

8) Nakano, S. and Ogawa, N.: Infuluence of anticholinergic agent on absorption and sedative effects of oral diazepam. IRCS Med. Sci.,8 : 54-55 (1980).

9) Greenblatt,D. J.,Allen, M. D., MacLaughlin,D. S. et al. : Diazepam absorption : Effect of antacids and food. Clin. Pharmacol. Ther., 24 : 600-609 (1978).

10）中野重行, 渡部博和, 小川暢也ほか：Diazepam の吸収と胃通過時間一胃切除術の影響一. 臨床薬理, $11: 371-372(1980)$.

11）渡部博和, 中野重行, 小川暢也 : 経口投与 Diazepam の Kineticsに及ぼす投与時刻の影響 とそのメカニズムに関する検討. 臨床薬理, 11 :367-368 (1980).

12) Rowland, M. and Tozer, T. : Clinical pharma- 
cokinetics: concepts and applications., Lea \& Febiger, pp. 34-46 (1980).

13）中野重行, 渡部博和, 小川暢也: 抗不安薬 （diazepam）の血漿蛋白結合とその意義一血 漿中ならびに喠液中濃度との関連性. 心身医学, 22 : 244-248 (1982).

14) Thiessen, J. J., Sellers, E. M., Denbeigh, P. et al. : Plasma protein binding of diazepam and tolbutamide in chronic alcoholics. J. Clin. Pharmac., 16 : 345-351 (1976).

15) Klotz, U., Antonin, K. H. and Bieck, P. R.: Pharmacokinetics and plasma binding of diazepam in man, dog, rabbit, guinea pig and rat. J. Pharmac, Exp. Ther., 199:67-73 (1976).

16) Van Der Keijn, E., Van Rossum, J. M., Mus: kens, E. T. J. M. et al. : Pharmacokinetics of diazepam in dogs, mice, and humans. Acta Pharmacol. Toxicol., 29 (Suppl. 3) : 109127 (1971).

17）中野重行, 渡部博和, 長井啓介ほか：Diazepam の薬物動態ならびに鎮静作用に及ぼす投
与時刻の影響。臨床薬理, $14: 99-100$ (1982).

18) Nakano, S.: Acute tolerance to diazepam in man after a single oral dose. IRCS Med. Sci.,8 :33-34 (1980).

19) Greenblatt, D. J., Woo, E., Allen, M. D. et al. : Rapid recovery from massive diazepam overdose. JAMA.,240:1872-1874 (1978).

20) Aitken, R. C. B. : Measurement of feelings using visual analogue scales. Proc. R. Soc. Med., 62 : 989-993 (1969).

21) Hayes, M. H. S. and Patterson, D. G. : Experimental development of the graphic rating method. Psychol. Bull.,18: 98-99 (1929).

22) Freyd, M. : The graphic rating scale. J. Educ. Psychol., 14 : 83-102 (1623).

23) Nowlis, V. and Nowlis, H. H. : The description and analysis of mood. Ann. N. Y. Acad. Sci., 65 :343-355 (1956).

24) Tyrer, P.: The role of bodily feelings in anxiety. Oxford University Press, pp.29-31 (1976). 